\title{
PENGARUH FAKTORPSIKOLOGIS TERHADAP KEPUTUSAN MEMBELI MOTOR MATIC YAMAHA MIO M3CW 125 DI KOTA PALU
}

\author{
PUJI ASTUTI \\ MASKURI SUTOMO \\ NIRWAN \\ Program Studi S1 Manajemen, Fakultas Ekonomi, Universitas Tadulako \\ Email: pujimanajemen14@gmail.com, maskuri.sutomo@yahoo.com
}

\begin{abstract}
The purpose of this study was to determine the influence of psychological factors on the decision to buy a Mio M3 CW 125 motorbike in Palu City. The research variables used were psychological factors consisting of motivation, perception, learning, belief, and attitude. While the dependent variable is the decision to buy (Y). The research method used is descriptive causal, with a sample of 90 people. The form of sampling uses accidental sampling technique. Data analysis method used in this study is a multiple linear regression analysis method. The results of this study indicate that: 1) psychological factors consisting of motivation, perception, learning, beliefs, and attitudes simultaneously have a significant effect on the decision to buy a Yamaha Mio M3 CW 125 motorbike; matic Yamaha Mio M3 CW 125; 3) perception partially has a significant effect on the decision to buy a Yamaha Mio M3 CW 125 motorbike; 4) learning partially influences significantly the decision to buy Yamaha Mio M3 CW 125; influential significantly influence the decision to buy a Yamaha Mio M3 CW 125 motorbike matic; 6) the attitude partially influences significantly the decision to buy a Yamaha Mio M3 CW 125 motorbike in Palu City.
\end{abstract}

Keywords: Psychological Factors, Buying Decisions

\section{Abstrak}

Tujuan penelitian ini adalah untuk mengetahui pengaruh faktor psikologis terhadap keputusan membeli motor matic Mio M3 CW 125 di Kota Palu.Variabel penelitian yang digunakan yaitu factor psikologisyang terdiri dari motivasi, persepsi, pembelajaran, keyakinan, dan sikap.Sedangkan variabel dependen yaitu keputusan membeli (Y). Metode penelitian yang digunakan bersifat deskriptif kausal,dengan jumlah sampel 90 orang. Bentuk pengambilan sampel menggunakan teknik accidental sampling. Metode analisis data yang digunakan dalam penelitian ini adalah metode analisis regresi linear berganda. Hasil penelitian ini menunjukan bahwa:1) faktor psikologis yang terdiri dari motivasi, persepsi, pembelajaran, keyakinan, dan sikap secara serempak berpengaruh signifikan terhadap keputusan membeli motor matic Yamaha Mio M3 CW 125;2) motivasi secara parsial berpengaruh berpengaruh signifikan terhadap keputusan membeli motor matic Yamaha Mio M3 CW 125;3) persepsi secara parsial berpengaruh berpengaruh signifikan terhadap keputusan membeli motor matic Yamaha Mio M3 CW 125;4) pembelajaran secara parsial berpengaruh berpengaruh signifikan terhadap keputusan membeli motor matic Yamaha Mio M3 CW 125;5) keyakinan secara parsial berpengaruh berpengaruh signifikan terhadap keputusan membeli motor matic Yamaha Mio M3 CW 125;6) sikap secara parsial berpengaruh berpengaruh signifikan terhadap keputusan membeli motor matic Yamaha Mio M3 CW 125 di Kota Palu.

Kata Kunci:Faktor Psikologis, Keputusan Membeli

\section{PENDAHULUAN}

Kebutuhan akan alat transportasi menjadikan kebutuhan yang sangat penting dan kompleks,dalam kehidupan masyarakat yang sangat sibuk dengan aktivitas sehari-hari, alat transportasi dapat menunjang aktivitas tersebut. Namun dengan banyaknya alat transportasi sekarang ini menjadikan jalan semakin macet terutama oleh kendaraan roda empat, untuk mengatasi hal tersebut salah satu 
pilihan yang tepat adalah memilih alat transportasi yang sederhana serta mudah diperoleh, berupa kendaraan roda dua atau sepeda motor

Sepeda motor merupakan salah satu alternatif bepergian dari suatu tempat ke tempat lain secara mudah, irit,cepat, luwes, efesien dan lain sebagainya. Bagi masyarakat yang berpenghasilan rendah, sepeda motor menjadi harapan satu-satunya untuk dapat memiliki alat transportasi darat pribadi sesuai dengan kemampuan ekonominya, tetapi tidak menutuk kemungkinan bagi masyarakat yang berpengahasilan menengah sampai berpenghasilan tinggi menggunakan motor untuk kepeluan sehariharinya, agar terhindar dari kemacetan lalu lintas kendaraan. Disisi lain dari kesederhanaannya dan semakin mudah memperolehnya menyebabkan permintaan akan sepeda motor menjadi semakin bertambah sehingga hal ini merupakan suatu kesempatan bagi perusahaan motor menawarkan hasil produksi serta inovasinya.

Salah satu produk terbaru dari sepeda motor adalah scooter yakni sepeda motor dengan teknologi matic. Diliat dari perkembangannya motor matic tidak lagi berfokus pada pengguna wanita, dan dapat digunakan untuk semua kalangan. Di Indonesia terdapat beberapa perusahaan besar, salah satu diantaranya Yamaha Indonesia Motor Manufacturing (YIMM) yang merupakan sebuah perusahaan besar yang memproduksi sepeda motor. Perusahaan ini didirikan pada 6 Juli1974, Pabrik sepeda motor Yamaha mulai beroperasi di Indonesia sekitar tahun 1969 sebagai suatu perusahaan perakitan saja, semua komponen didatangkan dari jepang.

Untuk menghadapi persaingan yang semakin ketat produk Yamaha selalu menciptakan penemuan baru yang disesuaikan dengan perkembangan zaman dan keinginan dari konsumen agar produknya tetap laku dipasaran. Dunia engineering kembali diguncang oleh teknologi terbaru Yamaha yang disebut dengan teknologi Blue Core. (Riana Dewie-Kompasiana.com 2015).

Kehadiran sepeda motor matik Yamaha Mio M3 CW 125 merupakan hasil dari teknologi blue core yang merupakan hasil pengembangan dari produk sebelumnya yaitu Yamaha Mio, angka 3 yang berada dibelakang huruf $\mathrm{M}$ memiliki arti generasi ketiga sekaligus penanda bahwa inilah generasi terbaru dari Yamaha Mio. Inovasi yang dihadirkan mulai dari desain, sampai dengan mesin terbaru yang identik dengan motor yang kencang, gesit, dan irit bahan bakar, dan memiliki target pangsa pasar berusia 17-25 tahun, alhasil pilihan warnanya sangat banyak, yaitu active green, awesome white, attractive red,dan amazing black.

Secara tampilan, skutik $125 \mathrm{cc}$ hadir dengan paras yang agresif disekitar tubuhnya, terdapat pula aksen karbon dilima area, yaitu cover mesin, panel depanduck samping, cover belakang, dan pelindung knalpot. Tujuannya adalah agar kesan sporty lebih terlihat. Sementara dalam hal mesin matic Mio M3 CW 125 dibekali silinder dengan system pendingin udara, mesin tersebut mampu menghasilkan torsi puncak 9,6 $\mathrm{nm}$ pada 5.500 dan tenaga maksimal 9,38 hppada 8000 hrpm.Munculnya Mio M3 CW 125 ditanggapi positif oleh konsumen di Kota Palu.

Berdasarkan data penjualan motor matic di area Kota Palu, Kab. Donggala dan Kab Sigi Biromaru diatas, dapat disimpulkan bahwa Motor Yamaha Matic Mio M3 125 menempati posisisi 1 sebagai market leader dari tahun 2015-2017, bahkan presentasi penjualan motor Mio M3 CW 125 pada tahun 2016 melonjak dari tahun sebelumnya, danmenyusul di tahun berikutnya penjualan mengalami penurunan, adapun penurunan pada tahun ini diduga kuat karena munculnya motor merek lain seperti Fino. Lebih lanjut data didukung oleh hasil wawancara dengan pemilik Toko Sentral Yamaha Walyosa Sagaladi S.sos pada jam 10.30 Wita, Senin, 21 Agustus 2017 mengemukakan bahwa untuk wilayah Kota Palu Sales Total Unit (STU) dari180 unit/bulan, Share Type Unit (STU) 51 \% Type Mio M3 CW 125 dan 49 lainnya merek lain.

Saat ini konsumen semakin cerdas dan selektif dalam memilih produk yang akan dikonsumsinya, hal tersebut menimbulkan persaingan yang semakin ketat antar produsen dalam usaha memperebutkan perhatian konsumen yang ada di pasar untuk membeli produknya. Salah satu faktor yang mempengaruhi dalam keputusan pembelian konsumen adalah faktor psikologis. Menurut Kotler \& Keller (2009:165), pembelian konsumen dapat dipengaruhi oleh beberapa karakteristik budaya, sosial, pribadi, dan psikologis, kemudian berikutnya dijelaskan bahwa "keputusan pembelian dipengaruhi oleh faktor psikologis yang meliputi motivasi, persepsi, pembelajaran, keyakinan, dan sikap". 
Pada umumnya konsumen membeli motor termotivasi untuk menikmati dua fungsi, yaitu sebagai sarana untuk menunjang aktivitas sehari-hari, sedangkan fungsi lainnya adalah untuk mendapatkan suatu prestise yang akan memberikan kepuasan tersendiri bagi seseorang, maka dapat dilihat motivasi dapat disebabkan oleh dorongan yang diakibatkan oleh kebutuhan seseorang yang tidak terpenuhi baik untuk penunjang kegiatan, hobi, dan kebutuhan akan prestise dimata konsumen

Pembelian produk khususnya sepeda motor dipengaruhi oleh persepsi konsumen dalam menginterpretasikan stimuli menjadi suatu gambaran yang bias berupa spesifikasi motor matic Yamaha Mio M3 CW 125 yang terdiri dari desain, warna, harga, kualitas, serta prestise yang diberikan sebagai pertimbangan yang dijadikan kesimpulan tentang pandangan seseorang

Berdasarkan kebutuhan dan pandangan seseorang, konsumen akan melalui tahap pembelajaran dimana tahap tersebut menggambarkan media yang dapat memudahkan konsumen memperoleh informasi, daya tarik dari media serta tingkah laku individual yang muncul dari pengalaman membeli sebelumnya.

Tahap akhir dalam pembentukan psikologis konsumen ialah keyakinan dan sikap, dimana dari adanya jaminan keamanan dan keselamatan pengguna serta kemudahan memperoleh produk akan membentuk keyakinan. Selanjutnya sikap muncul dapat dipengaruhi oleh beberapa factor diantaranya suka terhadap merek dan inovasi dari produk tersebut seperti atribut tambahan dari motor matic Mio M3 CW 125 yang merupakan generasi inovasi Yamaha Mio.

Perusahaan yang berorientasi pada konsumen, akan selalu beradaptasi dan bereaksi terhadap kebutuhan dan keinginan konsumen yang selalu berubah. Pengetahuan konsumen mengenai motor matic Yamaha Mio M3 CW 125 dalam menilai sejumlah mana faktor psikologis yang mendorong seseorang dalam melakukan pembelian akan berguna dalam penyusunan strategi pemasaran sesuai keinginan konsumen.

\section{KAJIAN LITERATUREDAN PENGEMBANGAN HIPOTESIS}

Menurut Swasta \& Handoko (2012:77) faktor-faktor psikologis yang berasal dari proses intern individu sangat berpengaruh terhadap keputusan pembelian konsumen. Teori-teori psikologis akan banyak membantu dalam memberikan pengetahuan tentang alasan menyangkut perilaku konsumen. Menurut Kotler \& Keller (2009:165)keputusan pembelian dipengaruhi oleh faktor psikologis yang meliputi motivasi, persepsi, pembelajaran, keyakinan, dan sikap.

Dharmesta \& Handoko (2011:76) motivasi merupakan kebutuhan dan keinginan individu yang diarahkan pada tujuan untuk memperoleh kepuasan.Schiffman \& Kanuk (2008:72) motivasi dapat diambarkan sebagai tenaga pendorong dalam diri individu yang memaksa mereka untuk bertindak.Jadi, motivasi muncul karena adanya kebutuhan yang harus dipenuhi. Kebutuhan inilah yang mendorong konsumen melakukan pembelian terhadap barang yang dibutuhkan

Kotler \& Keller (2009:179) persepsi adalah proses dimana kita memilih, mengatur, dan menerjemahkan masukan informasi untuk menciptakan gambaran dunia yang berarti. Schiffman \& Kanuk (2008:137) persepsi didefenisikan sebagai proses yang dilakukan individu untuk memilih, mengatur, dan menafsirkan stimuli agar ke dalam gambar yang berarti dan masuk akal mengenai dunia. Berdasarkan kedua defenisi tersebut dapat disimpulkan bahwa Persepsi merupakan proses dimana individu memilih dan menginterpretasikan sesuatu agar memiliki arti

Kotler \& Keller (2009:18) pengetahuan atau pembelajaran menggambarkanperubahan dalam tingkah laku individu yang muncul dari pengalaman. Schiffman \& Kanuk (2008:179) pembelajaran konsumen dapat dianggap proses bagi individu untuk memperoleh pengetahuandan pengalaman pembelian dan pemakaian yang mereka terapkan pada perilaku yang akandating. Jadi pembelajaran yaitu pemahaman atau pengertian terhadap suatu produk yang dianggap mampu memberikan kepuasan yang akan tersimpan dalam benak konsumen yang memiliki peranan penting untuk menentukan keputusan pembelian dimasa akan dating.

Kotler \& Keller (2009:186) keyakinan adalah pemikiran deskriptif yang dipegang seseorang tentang sesuatu.Assauri (2009:123) keyakinan adalah pemikiran deskriptif yang dianut seseorang tentang suatu hal.Keyakinan itu didasarkan atas pengetahuan, opini, dan keyakinan yang mungkin 
dipengaruhi dan tidak dipengaruhi oleh rasa emosional.Jadi keyakinan yaitu gagasan deskritif yang dianut seseorang tentang sesuatu.

Kotler \& Keller (2009:186) sikap(attitude) yaitu evaluasi dalam waktu lama tentang yang disukai atau tidak disukai seseorang, perasaan emosional, dan kecenderungan tindakan terhadap beberapa objek atau ide. Schiffman \& Kanuk (2008:222) dalam knteks perilaku konsumen sikap adalah kecenderungan yang dipelajari dalam berperilaku dengan cara yang menyenangkan atau tidak menyenangkan terhadap suatu obyek tertentu. Jadi sikap yaitu bentuk evaluasi individu terhadap produk atau jasa yang dipelajari dan kemudian dijadikan bahan pertimbangan dalam memutuskan pembelian.

Schiffman \& Kanuk (2008:485) keputusan adalah dua seleksi atas dua pilihan alternative atau lebih. Proses pembuatan keputusan merupakan hal ang sangat rumit ketika dihadapkan pada beberapa keputusan. Menurut Kotler \& Amstrong (2008:181) keputusan pembelian adalah kegiatan membeli merek yang disukai dan posisinya berada diantara dua faktor niat membeli dan melakukan keputusan pembelian.

\section{METODE PENELITIAN}

Jenis penilitian ini adalah penelitian deskriptif dan kausal. Objek penelitian (variabel penelitian) adalah segala sesuatu yang berbentuk apa saja yang ditetapkan oleh peneliti untuk dipelajari sehingga informasi tentang hal tersebut, kemudian ditarik kesimpulannya. Objek dalam penelitian ini adalah pengaruh faktor psikologis sebagai variabel yang memengaruhi (independen) sedangkan variabel yang dipengaruhi (dependen) ialah keputusan pembelian motor matic Yamaha Mio M3 CW 125 di Kota Palu.

Populasi dalam penelitian ini adalah konsumenpengguna motor matic Yamaha Mio M3 CW 125 di Kota Palu.. Metode pengambilan sampel yang digunakan dalam penelitian ini adalah non-probability sampling dan menggunakan teknik accidental sampling yaitu teknik dimana penentuan sampel dilakukan terhadap siapa saja yang dikehendaki peneliti dengan ketentuan responden merupakan pengguna motor motor matic Yamaha Mio M3 CW 125 di Kota Palu.

Jumlah sampel yang diambil untuk mewakili populasi dalam penelitian ini sebanyak 90 sampel. Penentuan sampel sebanyak 90 responden, ini didasarkan pada teori teori Roscoe dalam Sugiyono (2014:91) bila dalam penelitian akan melakukan analisis dengan multivariate (korelasi atau regresi berganda misalnya), maka jumlah anggota sampel minimal 10 kali dari jumlah variabel yang diteliti (independen + dependen).

Sebelum data dikumpulkan dan diolah, maka sebelumnya peneliti perlu melakukan uji coba instrumen terlebih dahulu, guna menegetahui tingkat validitas dan reliabilitas suatu instrument.

1. Uji Validitas

Uji validitas bertujuan untuk mengetahui apakah alat ukur yang telah disususn dapat digunakan untuk mengukur apa yang hendak diukur secara tepat..Validitas suatu Instrumen akan menggambarkan tingkat kemampuan alat ukur yang digunakan untuk mengungkapkan sesuatu yang menjadi sasaran pokok pengukuran. Sugiyono (2014:188) syarat minimum untuk dianggap memenuhi syarat adalah $\mathrm{r}=0.3$. Jadi, korelasi antara butir dengan skor total kurang dari 0.3 maka butir dalam instrument tersebut dinyatakan tidak valid. Sebaliknya, bila skor total sama dengan 0.3 atau lebih (paling kecil 0.3 ) maka instrumen tersebut dinyatakan valid

2. Uji Reliabilitas

Penerapan uji realibilitas adalah untuk mengetahui apakah alat pengumpulan data pada dasarnya menunjukan tingkat ketepatan dan keakuratan atas konsisten instrumen tersebut dalam mengungkapkan gejala tertentu.Suatu instrumen dikatakan reliabel manakala memenuhi standar koefesien alpha cronbach lebih besar dari 0.60 .

\section{Metode Analisis}

1. Uji Multikolinieritas

Uji Multikolinieritas digunakan untuk melihat ada tidaknya korelasi yang tinggi antara variabelvariabel bebas dalam suatu model regresi linear berganda. Jika terdapat korelasi yang tinggi 
diantara variabel-variabel bebas, maka hubungan antara variabel bebas dan variabel terikat akan terganggu. Ketentun dalam pengujian ini adalah :

a. Jika nilai tolerance $<0,10$ dan VIF $>$ maka terdapat korelasi yang terlalu besar diantara salah satu variabel bebas dengan variabel-variabel bebas lainnya (terjadi multikolinearitas)

b. Jika nilai tolerance $>0,10$ dan VIF $<$ maka tidak terjadi multikonearitas

2. Uji Heteroskedastisitas

Uji heteroskedastisitas dilakukan untuk mengetahui apakah dalam sebuah model regresi terjadi ketidaksamaan varians dari residual suatu pengamatan ke pengamatan lain. Jika variansdari residual satu pengamatan ke pengamatan lain tetap, maka disebut homoskedastisitas dan jika berbeda disebut heteroskedastisitas Model regresi yang baik adalah tidak terjadi heteroskedastisitas.

3. Uji Normalitas

Asumsi normalitas konsen pada tingkat persebaran data atau skor berkisar pada distribusi standar baku atau standar normal, atau kurva normal (Sudarmanto 2013:101). Asumsi normalitas dimaksudkan bahwa sebaran skor tidak menyimpang secara signifikan dari distribusi normal yang simetrik atau tidak menceng secara signifikan.

4. Regresi Linear Berganda

Untuk menguji pengaruh variabel factor psikologis yang terdiri dari motivasi, persepsi pembelajaran, keyakinan, dan sikap terhadap keputusan membeli motor matic Yamaha Mio M3 CW 125, maka digunakan alat uji statistik yaitu regresi linear berganda yang dapat dirumuskan (Rangkuti:165).

$$
\mathbf{Y}=\mathbf{a}+\mathbf{b}_{1} \mathbf{X}_{1}+\mathbf{b}_{2} \mathbf{X}_{2}+\mathbf{b}_{3} \mathbf{X}_{3}+\mathbf{b}_{4} \mathbf{X}_{4}+\mathbf{b}_{5} \mathbf{X}_{5}+\mathbf{e}
$$

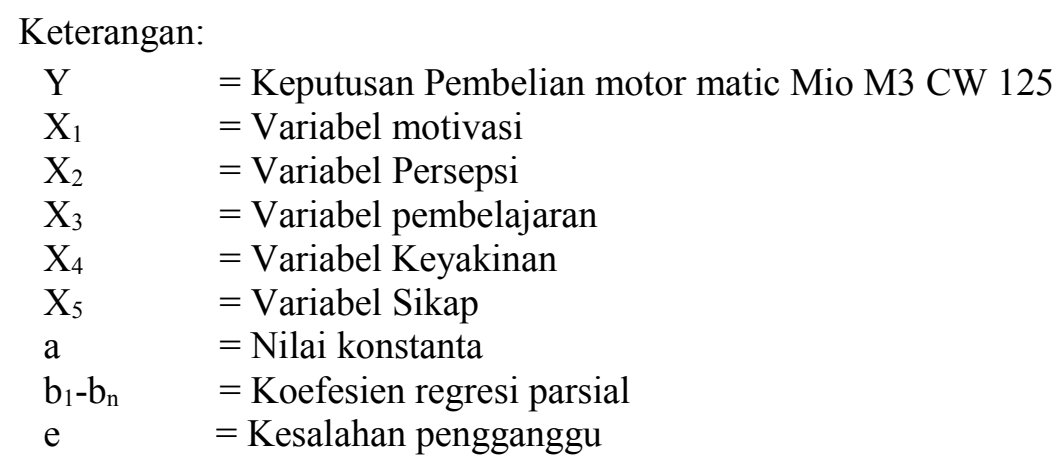

\section{HASIL DAN PEMBAHASAN}

Penelitian ini menggunakan analisis regresi linear berganda dengan tujuan untuk menguji pengaruh factor psikologis yang terdiri dari motivasi, persepsi, pembelajaran, keyakinan, dan sikap terhadap keputusan pembelian.Untuk lebih jelasnya hasil analisis regresi linear berganda dapat dilihat pada tabel 2 berikut:

Tabel 1. Ringkasan Hasil Olah Regresi Linear Berganda

Coefficients

\begin{tabular}{cccccc}
\hline \multirow{2}{*}{ Model } & \multicolumn{2}{c}{$\begin{array}{c}\text { Unstandardized } \\
\text { Coefficients }\end{array}$} & $\begin{array}{c}\text { Standardizd } \\
\text { Coefficients }\end{array}$ & \multirow{2}{*}{ T } & \multirow{2}{*}{ Sig } \\
\cline { 2 - 4 } & $\mathbf{B}$ & Std. Error & Beta & & \\
\hline (Constant) & 0,565 & 0,494 & & 1.145 & 0,256 \\
\hline Motivasi & 0,176 & 0,055 & 0,247 & 3.202 & 0,002 \\
\hline
\end{tabular}




\begin{tabular}{lccccc}
\hline Persepsi & $-0,163$ & 0,061 & $-0,203$ & -2.677 & 0,009 \\
\hline Pembelajaran & 0,156 & 0,066 & 0,181 & 2.369 & 0,020 \\
\hline Keyakinan & 0,473 & 0,073 & 0,497 & 6.464 & 0,000 \\
\hline Sikap & 0,231 & 0,067 & 0,273 & 3.467 & 0,001 \\
\hline $\boldsymbol{R}$ Square & $\mathbf{= 0 , 5 4 2}$ & Sig -t & $=\mathbf{0 0 , 0 0 5}$ & & \\
\hline Adjusted $\boldsymbol{R}$ Square $=\mathbf{0 , 5 1 5}$ & Sig-F & $\mathbf{= 0 , 0 0 0 \alpha}$ & & \\
\hline \multicolumn{7}{l}{ Multiple $\boldsymbol{R}$} & $\mathbf{0 , 7 3 6}$ & & & & \\
\hline
\end{tabular}

Sumber: Data diolahTahun 2018

Berdasarkan tabel 2 tersebut, dapat ditulis dalam bentuk persamaan regresi linear berganda.Untuk lebih jelasnya bentuk persamaan tersebut dapat dilihat sebagai berikut:

$$
Y=0,565+0,176\left(X_{1}\right)+-0,163\left(X_{2}\right)+0,156\left(X_{3}\right)+0,473\left(X_{4}\right)+0,231\left(X_{5}\right)
$$

Berdasarkan penjabaran tersebut menunjukkan bahwa, variabel independen yang dianalisis yaitu variabel $\left(\mathrm{X}_{1}, \mathrm{X}_{3}, \mathrm{X}_{4}\right.$, dan $\left.\mathrm{X}_{5}\right)$ memberikan pengaruh positif sedangkan $\left.\mathrm{X}_{2}\right)$ memberikan pengaruh negative terhadap variabel dependen (Y), yaitu keputusan pembelian motor matic Mio M3 CW 125 di Kota Palu. Untuk lebih jelasnya penjelasan bentuk persamaan tersebut dapat dilihat berikut ini:

1. a (constant) adalah 0.565 , artinya jika motivasi $\left(\mathrm{X}_{1}\right)$, persepsi $\left(\mathrm{X}_{2}\right)$, pembelajaran $\left(\mathrm{X}_{3}\right)$ keyakinan $\left(\mathrm{X}_{4}\right)$ dan sikap $\left(\mathrm{X}_{5}\right)$ nilainya 0 (nol) maka keputusan membeli (Y) motor matic Yamaha Mio M3 CW 125 di Kota Palu akan meningkat sebesar 0.565 atau $56.5 \%$.

2. Nilai koefisien regresi variabel motivasi $\left(\mathrm{X}_{1}\right)$ bernilai 0.176 . Hal ini menunjukan bahwa apabila nilai motivasi naik satu satuan, maka akan diikuti oleh kenaikankeputusan membelimotor matic Yamaha Mio M3 CW 125 di Kota Palu akan meningkat

3. Nilai koefisien regresi variabel persepsi $\left(\mathrm{X}_{2}\right)$ bernilai -0.163 . Hal ini menunjukan bahwa apabila nilai persepsi meningkat, maka akan diikuti oleh penurunan keputusan membelimotor matic Yamaha Mio M3 CW 125 di Kota Palu

4. Nilai koefisien regresi variabel pembelajaran $\left(\mathrm{X}_{3}\right)$ bernilai 0.156 . Hal ini menunjukan bahwa apabila nilai pembelajaran meningkat, maka akan diikuti oleh kenaikan keputusan membeli motor matic Yamaha Mio M3 CW 125 di Kota Palu

5. Nilai koefisien regresi variabel keyakinan $\left(\mathrm{X}_{4}\right)$ bernilai 0.473 . Hal ini menyatakan bahwa bila nilai keyakinan meningkat, maka akan diikuti oleh kenaikankeputusan membelimotor matic Yamaha Mio M3 CW 125 di Kota Palu

6. Nilai koefisien regresi variabel sikap $\left(\mathrm{X}_{5}\right)$ bernilai 0.231 . Hal ini menyatakan bahwa bila nilai keyakinan meningkat, maka akan diikuti oleh kenaikan keputusan membeli motor matic Yamaha Mio M3 CW 125 di Kota Palu.

Tahap selanjutnya adalah menguji signifikan hubungan atau uji $\mathrm{F}$ antara variabel penelitian yaitu factor psikologis (X) terhadap keputusan pembelian (Y) dengan perhitungan menggunakan SPSS 16.0 dengan hasil sebagai berikut:

\section{Uji F}

Berdasarkan hasil analisis regresi linear berganda diperoleh nilai signifikansi $\mathrm{F}$ (sig F) $0,000<\alpha$ $(0,05)$, dengan demikian dapat diketahui bahwa variabel aktor psikologis yang atas motivasi $\left(\mathrm{X}_{1}\right)$, persepsi $\left(\mathrm{X}_{2}\right)$, pembelajaran $\left(\mathrm{X}_{3}\right)$, dan keyakinan $\left(\mathrm{X}_{4}\right)$, dan sikap $\left(\mathrm{X}_{5}\right)$ secara serempak berpengaruh signifikan terhadap keputusan membeli motor matic Yamaha Mio M3 CW 125 di Kota Palu. Y.

Hasil Uji $t$ adalah untuk mengetahui apakah variabel $\left(\mathrm{X}_{1}-\mathrm{X}_{2}\right)$ secara parsial berpengaruh terhadap

\section{Uji t}

Hasil uji t pengujian variabel $\left(\mathrm{X}_{1}-\mathrm{X}_{5}\right)$ terhadap $\mathrm{Y}$ dijelaskan sebagai berikut: 
1. Hasil uji t untuk variabel faktor psikologis yaitu motivasi diperoleh nilai signifikan0.002 $<\alpha$ (0.05), dapat disimpulkan bahwa motivasi secara parsial berpengaruh positif dan signifikan terhadap keputusan membeli motor matic Yamaha Mio M3 CW 125 di Kota Palu. Hal ini menunjukan berarti bahwa hipotesis diterima kebenarannya

2. Hasil uji t untuk variabel persepsi diperoleh nilai signifikan0.009 $\leq \alpha(0,05)$, dapat disimpulkan bahwa persepsi secara parsial berpengaruh negatif dan signifikan terhadap keputusan membeli motor matic Yamaha Mio M3 CW 125 di Kota Palu. Hal ini menunjukan berarti bahwa hipotesis diterima kebenarannya

3. Hasil uji t untuk variabel pembelajaran diperoleh nilai signifikan $0,020 \leq \alpha(0,05)$, dapat disimpulkan bahwa pembelajaran secara parsial berpengaruh positif dan signifikan terhadap keputusan membeli motor matic Yamaha Mio M3 CW 125 di Kota Palu. Hal ini menunjukan berarti bahwa hipotesis diterima kebenarannya

4. Hasil uji $t$ untuk variabel keyakinan diperoleh nilai signifikan $0,000<\alpha(0,05)$, apat disimpulkan bahwa keyakinan secara parsial berpengaruh signifikan terhadap keputusan membeli motor matic Yamaha Mio M3 CW 125 di Kota Palu.

5. Hasil uji t untuk variabel sikap diperoleh nilai signifikan $0,005 \leq \alpha(0,05)$, dapat disimpulkan bahwa sikap secara parsial berpengaruh positif dan signifikan terhadap keputusan membeli motor matic Yamaha Mio M3 CW 125 di Kota Palu. Berdasarkan hal ini berarti bahwa hipotesis diterima kebenarannya.

Berdasarkan hasil pengujian hipotesis terlihat bahawa variabel faktor psikologis yang terdiri dari motivasi, persepsi, pembelajaran, keyakinan dan sikap secara serempak berpengaruh signifikan terhadap keputusan membelimotor matic Yamaha Mio M3 CW 125 di Kota Palu, dengan nilai signifikansi F (Sig F) $0,000<\alpha(0,05)$, dengan demikian ketika konsumen mempunyai motivasi atau dorongan kebutuhan untuk menunjang pekerjaan dan mengikuti trend kehidupan, kemudian mempunyai persepsi yang tinggi, sesuai dengan pengetahuan mereka akan kebaikan serta daya tarik dari produk dan dengan pembelajaran yang memadai yang dapat diperoleh dari berbagai media dan pengalaman akan pembelian produk, serta keyakinan yang didasarkan pada jaminan keselamatan dan keamanan pengguna serta berupa pembentukan sikap didasrkan pada merek dan atribut tambahan yang menyertainya akan mendorong konsumen dalam keputusan untuk membelimotor matic Yamaha Mio M3 125 di Kota Palu.Penelitian ini didukung oleh Heny Supriyanti (2012), yaitu melihat pengaruh factor psikologis yang memiliki pengaruh positif dn signifikan terhadap keputusan pembelian Honda Vario di Surabaya.

Motivasi memiliki pengaruh positif dan signifikan terhadap keputusan membeli, dalam penelitian ini motivasi diartikan sebagai suatu dorongan baik dari faktor internal yaitu kebutuhan untuk menunjang pekerjaan maupun faktor eksternal yang berasal dari lingkungan berupa penggunaannya lagi trendy. Berdasarkan dari hasil uji regresi yang telah diamati dan dikaitkan dengan fenomena yang ada bahwasanya konsumen di Kota Palu khususnya usia remaja sampai dewasa melakukan pembelian dipengaruhi oleh kebutuhan berkendara dan trendy dari dari Mio M3 CW 125. Hal tersebut secara fenomena didukung kuat oleh informasi dari media yang diperoleh peneliti yang dijadikan landasan pada latar belakang penelitian, bahwa pengguna atau daya tarik Mio M3 CW 125 mampu berinovasi dan menjawab kebutuhan akan konsumen masa kini.Lebih lanjut pengaruh antar variabel didukung oleh penelitian yang dilakukan oleh Heny Supriyanti (2012), yaitu melihat pengaruh faktor psikologis memiliki pengaruh positif dan signifikan terhadap keputusan konsumen dalam pembelian Honda Vario di Surabaya.

Persepsi memiliki pengaruh negatif dan signifikan terhadap Keputusan Membeli Motor Matic Yamaha Mio M3 CW 125 Di Kota Palu Berdasarkan dari hasil uji regresi yang telah diamati dan dikaitkan dengan fenomena yang ada bahwasanya konsumen mio M3 CW 125 di Kota Palu lebih cenderung membeli karena memiliki kombinasi yang serasi serta daya tahan mesin yang baik yaitu dikarenakan motor mio M3 CW 125 bukan lagi hanya sekedar alat transportasi melainkan sudah banya fitur-fitur yang terintegrasi didalamnya dan teknologi terbaru dari generasi Mio yang selalu melakukan inovasi dan berkembang sehingga teknologi yang ditawarkan adalah teknologi yang layak dan modern untuk dijadikan alternatif terbaik dalam keputusan membeli. Berdasarkan fenomena yang ada, nilai 
negatif atau hubungan yang tidak searah diduga kuat disebabkan oleh beberapa alasan diantaranya karakteristik dominan dari responden yaitu perempuan, dimana kecenderungan perempuan yang berkendara dengan kecepatan rendah menjadikan Mio M3 CW 125 atau memiliki cc 125 kurang cocok dibandingkan generasi sebelumnya jika diliat dari sisi mesin, seperti Mio soul GT dengan cc 110. Alasan lainnya selain hadir dengan teknologi terbaru dan beberapa keunggulan Mio M3 CW 125 terlihat belum bisa menyamai pesaingnya seperti Honda Vario Esp 125 yang menawarkan bagasi yang lebih luas yang mampu menjawab kebutuhan wanita yaitu untuk menyimpan banyak barang atau bawaan.Hasil penelitian ini juga didukung oleh penelitian yang dilakukan oleh Heni Supriyanti (2013), yaitu melihat pengaruh persepsi kualitas terhadap keputusan membeli dari penelitian tersebut menunjukkan bahwa persepsi berpengaruh signifikan terhadap keputusan membeli.

Pembelajaran memiliki pengaruh positif dan signifikan terhadap keputusan membeli motor matic Mio M3 CW 125 di Kota Palu. Hasil uji regresi mengindikasikan bahwa konsumen Kota Palu akan cenderung melakukan keputusan membeli suatu produk yang mempunyai kesan-kesan yang baik di dalam ingatanya, hal ini dikarenakan secara psikologis konsumen akan menyukai suatu hal yang mudah, iklan menarik, dan sudah mempunyai citra positif di mata masyarakat dan adanya kesan positif yang kuat saat penggunaan terhadap merek tersebut di masa lalu sehingga hal inilah menjadi pertimbangan yang kuat untuk memutuskan membeli motor matic Mio M3 CW 125 di Kota Palu.Melihat fenomena yang ada bahwasanya konsumen Kota Palu mempunyai keputusan membeli motor matic Mio M3 CW 125 dengan mudah, tampilan iklan dapat diperoleh dimana saja, dan dikarenakan pengalaman membeli dan sudah mempunyai citra positif di mata masyarakat dari adanya kesan positif yang kuat saat penggunaan terhadap merek tersebut di masa lalu sehingga hal inilah menjadi pertimbangan yang kuat untuk memutuskan membeli motor matic Mio M3 CW 125 di Kota Palu.Hasil penelitian ini juga didukung oleh penelitian yang dilakukan oleh Silsilya (2014), yaitu melihat pengaruh faktor psikologis terhadap keputusan pembelian pada PT. Conbloc Indonesia Surya Manado, dari penelitian tersebut menunjukan bahwa variabel pembelajaran memiliki pengaruh yang signifikan.

Keyakinan memiliki pengaruh yang positif dan signifikan. Berdasarkan dari hasil uji regresi yang telah diamati dan dikaitkan dengan fenomena yang ada bahwasanya konsumen di Kota Palu cenderung memutuskan membeli motor matic Yamaha Mio M3 CW 125 dikarenakan adanya kepercayaan yang kuat antara konsumen dengan produk dan perusahaan penyedia yang dianggap terpercaya dan mendukung keamankan serta keselamatan pengguna, berupa service secara berkala dan fasilitas berkendara seperti helm, jaket, kunci cadangan, serta plat nomer sebagai identitas dari produk, hal lain yang juga mendukung adalah penyedia produk, dalam hal ini dealer resmi sehingga produk terpercaya dan diakui,serta memiliki cabang yang tersebar di Kota Palu.Sehingga konsumen dengan mudah memperoleh produk yang diinginkan. Penelitian ini menunjukan bahwa mayoritas konsumen mempunyai gagasan yang kuat atau memutuskan membeli maka motor matic Yamaha Mio M3 CW 125 sebagai altenatif pilihan yang pertama, hal tersebut dapat dilihat dari hasil yang diperoleh tinggi dan merupkan variabel dengan pengaruh yang dominan.Hasil penelitian ini juga didukung oleh penelitian yang dilakukan oleh Dimas Fauzie dkk (2016) Pengaruh Faktor Psikologis Konsumen Terhadap Keputusan Pembelian (Survei Pada Konsumen KFC Cabang Mall Olympic Garden Malang), dari penelitian tersebut terlihat bahwa variabel yang memiliki pengaruh dominan dari faktor psikologis Konsumen yang mempengaruhi Struktur keputusan pembelian (Y) ialah variabel Keyakinan dan Sikap (X4)

Sikap memiliki pengaruh yang positif dan signifikan terhadap keputusan membeli motor matic Yamaha Mio M3 CW 125di Kota Palu. Berdasarkan dari hasil uji regresi yang telah diamati dan dikaitkan dengan fenomena yang ada bahwasanya konsumen di Kota Palu cenderung memutuskan membelimotor matic Yamaha Mio M3 CW 125 yaitu dikarenakan adanya pembentukan sikap yang didasarkan kesukaan pada merek dan atribut tambahan dari produk motor matic Yamaha Mio M3 CW 125 seperti berbagai corak warna, knalpot yang sport, dan sebagainya. Beberapa penelitian menunjukan bahwa variabel keyakinan dan sikap selalu beriringan, hal tersebut dikarenakan konsumen yang suka atau bersikap positif terhadap suatu produk cenderung memiliki keinginan yang kuat untuk memilih dan membeli produk yang disukainya.Hasil penelitian ini juga didukung oleh 
penelitian yang dilakukan oleh Dimas Fauzie dkk (2016) Pengaruh Faktor Psikologis Konsumen Terhadap Keputusan Pembelian (Survei Pada Konsumen KFC Cabang Mall Olympic Garden Malang).

\section{PENUTUP}

1. Hasil pengujian deternas ganda uji serempak (Uji-F), variable faktor psikologis yang terdiri dari motivasi $\left(\mathrm{X}_{1}\right)$, persepsi $\left(\mathrm{X}_{2}\right)$, pembelajaran $\left(\mathrm{X}_{3}\right)$ Keyakiann $\left(\mathrm{X}_{4}\right)$, dan sikap $\left(\mathrm{X}_{5}\right)$ secara serempak berpengaruh dan signifikan terhadap keputusan membeli motor matic Yamaha Mio M3 CW 125 di Kota Palu.

2. Hasil pengujian determinasi ganda uji parsial (Uji-t) secara parsial motivasi $\left(\mathrm{X}_{1}\right)$ berpengaruh positif dan signifikan terhadap keputusan membeli motor matic Yamaha Mio M3 CW 125 di Kota Palu

3. Hasil pengujian determinasi ganda uji parsial (Uji-t)secara parsial persepsi $\left(X_{2}\right)$ mempunyai pengaruh negatifdan signifikan terhadap keputusan membeli motor matic Yamaha Mio M3 CW 125 di Kota Palu.

4. Hasil pengujian determinasi ganda uji parsial (Uji-t) secara parsialpembelajaran $\left(\mathrm{X}_{3}\right)$ berpengaruh positif dan signifikan terhadap keputusan membeli motor matic Yamaha Mio M3 CW 125 di Kota Palu

5. Hasil pengujian determinasi ganda uji parsial (Uji-t) secara parsialkeyakinan $\left(\mathrm{X}_{4}\right)$ berpengaruh positif dan signifikan terhadap keputusan membeli motor matic Yamaha Mio M3 CW 125 di Kota Palu

6. Hasil pengujian determinasi ganda uji parsial (Uji-t) secara parsialsikap $\left(\mathrm{X}_{5}\right)$ berpengaruh positif dan signifikan terhadap keputusan membeli motor matic Yamaha Mio M3 CW 125 di Kota Palu

1. Memberikan perhatian lebih terhadap variabel faktor psikologis khususnya pada variabel persepsi yang memiliki pengaruh negatif, yang artinya bahwa desain tampilan fisik serta keadaan mesin atau bagian inti dari dari motor tersebut perlu terus dilakukan inovasi. Karena persepsi adalah aset yang tidak kelihatan yang keberadaanya dan cukup berpengaruh pada penghasilan perusahaan, maka penelitian seperti ini harus menjadi pertimbangan dalam pengambilan kebijakan perusahaan

2. Kepada peneliti selanjutnya diharapkan dapat meneliti mengenai faktor psikologis terhadap keputusan membeli motor matic Yamaha Mio M3 CW 125 di Kota Palu, untuk dapat mengkombinasikan variabel-variabel lain yang mempengaruhi untuk melakukan keputusan membeliagar hasil didapatkan akan lebih maksimal.

\section{REFERENSI}

Dewie Riana, Kompasiana.com. (2015). Bukti Kolaborasi Tangguh Yamaha Blue Core dan Pertalite. Diakses 6 September 2015

Assauri, Sofyan. (2009). Manajemen Pemasaran. Jakarta: PT Raja Grafindo Persada

Dharmesta, Basu Swasta dan T. Han Handoko.(2011). Manajemen Pemasaran : Analisis Perilaku Konsumen. Edisi Pertama. Yogyakarta: BPFE

Fauzie Dimas, Edy Yulianto, Sunarti. (2016). Pengaruh Faktor Psikologis Terhadap Keputusan Pembelian (Survey pada Konsumen KFC Cabang Mall Olympic Garden Malang).Jurnal Administrasi Bisnis(JAB), Vol. 40, No. 1

Kotler, P., \& Armstrong, G. (2008). Prinsip-prinsip Pemasaran (12 ed.). Jakarta: Erlangga.

Kotler, P., \& Keller, K. L. (2009). Manajemen Pemasaran (13 ed.). Jakarta: Erlangga

Retor Silsilya Truly.(2014). Analisis Motivasi, Persepsi, Pembelajaran, Keyakinan, dan Sikap Terhdap Keputusan Pembelian pada PT Conbloc Indonesia Surya Manado.Jurnal EMBA, Vol 2, No 3, September 2014 
Sciffman, L. ., \& Kanuk, L. L. (2008). Perilaku Konsumen. Edisi Ketujuh. Alih Bahasa oleh Zoelkifli Kasip. Jakarta: PT Indeks.

Sugiyono. (2014). Metode Penelitian Kuantitatif dan Kualitatif. Bandung: Alfabeta

Sudarmanto, R. Gunawan (2013).Statistik berbasis Terapan Berbasis Komputer dengan Program IBM SPSS Statistic 19. Jakarta: PT Mitra Wacana Media

Supriyanti Heni. (2012). Pengaruh Faktor Psikologis Terhadap Keputusan Konsumen dalam Pembelian Honda Vario di Surabaya.Jurnal Ilmu \& Riset Manajemen, Vol.1, No. 8

Swasta, Basu dan Handoko t. Hani.(2012). Manajemen Pemasaran dan Perilaku Konsumen. Cetakan Ketiga. Jakarta: Gramedia 